№27 (2018) стор. 227-234

The National Academy of Fine Arts and Architecture

Ukrainian Academy of Fine Art. Research and Methodology Papers

ISSN 2411-3034

Website: http://naoma-science.kiev.ua/

УДК75:7.041.5:7.01

ORCID 0000-0003-3394-7391

DIO: https://doi.org/10.33838/naoma.27.2018.227-234

\title{
Ольга Тарасенко
}

доктор мистеитвознавства, професор oa_tarasenko@ukr.net

\section{ОБРАЗ РОДУ І НАРОДУ У ТВОРЧОСТІ РОМАНА ПЕТРУКА}

\begin{abstract}
Анотація. У статті аналізуються створені Романом Петруком портретні образи його учителя - видатного украӥнського художника і педагога Миколи Стороженка, викладачів НАОМА, творчих людей Украӥни. Показано ритуальне призначення портрета, щуо забезпечує зв'язок світів - поцейбічного $і$ потойбічного, тимчасового й вічного. Розкрито особливості композиції, символіки та стилістики творів Петрука у контексті мистецтвва світового портрета.
\end{abstract}

Стаття проілюстрована роботами Романа Петрука.

Ключові слова: образ роду i народу, портрет і ритуал, духовність, художник, Роман Петрук, Микола Стороженко.

\section{ОБРАЗ РОДА И НАРОДА В ТВОРЧЕСТВЕ РОМАНА ПЕТРУКА.}

Ольга Тарасенко

Аннотация. В статье анализируются созданные Романом Петруком портретные образы его учителя выдающегося украинского художника и педагога Николая Стороженка, преподавателей НАОМА, творческих людей Украины. Показано ритуальное значение портрета, который обеспечивает связь миров посюстороннего и потустороннего, временного и вечного. Раскрыты особенности композиции, символики и стилистики произведений Петрука в контексте искусства мирового портрета.

Статья проиллюстрирована работами Романа Петрука.

Ключевые слова: образ рода и народа, портрет и ритуал, духовность, художник, Роман Петрук, Николай Стороженко.

\section{IMAGE OF THE FAMILY AND PEOPLE IN THE ARTWORK OF ROMAN PETRUCK.}

Olga Tarasenko

Abstrakt. Heroes of portraits of Roman Petruk are open-world creative people - his teachers, parents, of the same age - young artists, actors in whose faces the reality of the Spirit is manifested, the movement of life. The article analyzes Petruk's portraits of his teacher, an outstanding Ukrainian artist and teacher, Nikolai Andreevich Storozhenko and teachers of NAOMA. The ritual value of a portrait is shown, which provides the connection of the worlds - temporary and eternal. The symbolic content of portraits, the value of the conditional background in character characteristics is studied. The relationship between content and form, features of composition, symbols and stylistics of portrait images of the Ukrainian artist in the context of world art is revealed. Methods of iconography and iconography are used.

The main thing in the school of Storozhenko: the means of art combine in man the lost integrity of the body, soul 
and spirit. In the compositions of Petruk, secular and cult art was consonant. Following the teacher, Roman communicates the time: man and family, family and people, people and humanity.

In Storozhenko's portraits Petruk asserts the highest hierarchy of the artist-creator. The connection with portraits of avant-garde masters is shown. The relationship between the portrait and the icon in the portraits of Petruk is studied. The icon confirms the dominant spirit of peace, and emotionality is important in a psychological portrait. The work of the artist combines the legacy of the art of Ancient Rus and Byzantium, the European and Ukrainian Baroque, romanticism, and academicism with modern trends. Neosynthesticism - in such a way named his method Petruk.

The gallery of portrait images created by Roman Petruk (more than 100 works of painting and graphics) is a testimony to the spiritual battle of the artist for the dominant of spirit over matter. The general scientific significance of the article is the introduction of a modern Ukrainian portrait into the context of world art.

Key words: portrait and ritual, image of the genus and people, spirituality, artist, Roman Petruk, Mykola Storozhenko.

Постановка проблеми. Роман Петрук - молодший $з$ шести посвячених, кому вчитель омив ноги, повторивши обряд ініціації, відображений у грандіозній композиції «Передчуття Голгофи» (Микола Стороженко).

У 2015 році під керівництвом М. А. Стороженка Петрук закінчив навчально-творчу Майстерню живопису і храмової культури НАОМА. Художникові важливо усвідомлювати свою місію, розуміти сенс того, про що він покликаний говорити. Головне у школі Стороженка: засобами мистецтва поєднати в людині втрачену цілісність тіла, душі і духу. Микола Андрійович навчав: Зміст - це не сюжет - «це означає внесок душі» (Микола Стороженко). Роман пише портрети, тематичні композиції, ікони. Герої портретів - відкриті світові творчі люди - мудрі старі та безхитрісні чисті діти, його вчителі, батьки, однолітки - молоді художники, актори, в обличчях яких проявлена реальність Духа, рух життя.

Учитель «сповідував ідеї Сковороди», йому була співзвучна «Філософія серця» українського мудреця. Сердечність, співчуття - риси, притаманні професорові - втілені в його творчості і творах учнів. Божественне начало Стороженко вбачав у кожній людині:

Христос - він як душа, ця душа з'явилась на землі, ця душа - вона серед нас, вона вселяється в кожного $з$ нас аби очистити нас. Всі люди на землі наділені божественною силою, божество в людині. (Микола Стороженко)

Подібно до М. В. Гоголя, який прагнув через поему «Мертві душі» воскресити божественне в людині, слідом за Кобзарем М. А. Стороженко присвятив життя пробудженню душ людей за допомогою мистецтва, що має велику емоційну і духовну силу. Пензель був його полум'яним духовним мечем.

Актуальність дослідження. «Найскладніше піти від егоїстичного Я», - навчав Стороженко (Микола Стороженко). У період поп-культури показником глухого кута в зосередженості на своєму Его є селфі. Багато хто не пам'ятає трагічний фінал Нарциса, покараного коханням до самого себе. Втрачено гармонію між людьми, природою, небом. Забуто ритуальне призначення портрета, що забезпечує зв’язок світів поцейбічного і потойбічного, тимчасового і вічного. В останній день перед відходом до іншого світу Микола Андрійович прийшов до Романа в майстерню, де той писав масштабну дипломну роботу «Лісова пісня». «У той день говорили про все на світі», - згадує Петрук. Учитель доторкнувся носом до носа учня, глянувши в його очі як у дзеркало, і сказав: «Не прощаємось!» Цю заповітну фразу Стороженко повторював в останні роки життя. Оскільки Дух вічний, то зв’язок не переривається: «Життя триває, трансляції ідуть», - зізнається Роман (Розмова 1).

Мета роботи: розглянути створені Петруком портретні образи Миколи Андрійовича Стороженка, викладачів НАОМА, творчих людей України у контексті зв'язку роду й народу. Для дослідження автором використано насамперед методи іконології та іконографії.

Зв'язок авторського доробку 3 важливими науковими та практичними завданнями. Стаття виконана відповідно до плану наукової роботи кафедри образотворчого мистецтва ПНПУ імені К. Д. Ушинського.

Аналіз останніх досліджень та публікацій. При написанні статті ми спиралися на теорію мистецтва портрета П. Флоренського, Б. Віппера П. Білецького 
та власні дослідження. Важливими джерелами були: документальний фільм «Микола Стороженко. Передчуття Голгофи», бесіди з Р. Петруком та його статті.

Зазначення невирішених раніше частин загальної проблеми, яким присвячується стаття. У статті увагу зосереджено на портретних образах, створених Р. Петруком відповідно до творчих настанов учителя.

Новизна наукового дослідження. Творчості Р. Петрука присвячена стаття Р. Михайлової, але портрети М. Стороженка ще не були предметом спеціального наукового дослідження.

Методологічне або загальнонаукове значення авторських розробок. Загальнонаукове значення статті полягає у введенні сучасного українського портрета в контекст світового мистецтва.

Виклад основного матеріалу. Психологічний портрет - поєднання автора і моделі (Виппер 34251). Помічено, що створення портретного образу схоже до вживання актора в роль. Художник має можливість глибоко відчути, зрозуміти, прийняти i полюбити іншу людину. Для цього необхідна напружена душевна робота. Як компенсація відбувається збагачення особистості через розширення свідомості (не тільки автора, а й моделі). Роман пише натхненно. Часто лише нічна тиша дозволяє зосередитися. Він не пише портрети на замовлення, а тільки «від великої любові». Художник шукає форму втілення вічного духу в реальних людях, створюючи теплі, емоційно рухливі образи сучасників.

Сучасний європейський портрет через мистецтво Ренесансу, а потім бароко, має зв'язок, насамперед, з мистецтвом Стародавнього Риму, в культурі якого був розвинений культ предків. Під час похоронного обряду за допомогою масок людина поєднувалася з предками (Бритова, Лосева та Сидорова 17-18). Відомо, що робився восковий зліпок з обличчя померлого, а за ним - не тільки посмертний портрет-пам'ятник, але й маска. Актори одягали маски членів аристократичних родів і оживляли їх дійством. Предки ніби оживали, приймаючи до свого товариства нового члена. Під час ритуальної ходи нащадки несли портрети предків, стверджуючи силу - гармонію роду. Здійснювався також зв'язок світу потойбічного і поцейбічного. Таким чином стародавні римляни поєднувалися з численним родом і уникали страху смерті. Здійснюючи зв'язок часів: людини і роду, роду і народу, народу і людства -М. А. Стороженко створив портрети діячів української науки і культури: Григорія Сковороди, Максима Березовського, Петра Могили, Феофана Прокоповича та ін. Найважливіше місце займає образ Кобзаря у монументальному панно «Осяяні світлом» (1979-1981) Інституту фізики НАН України - у нерозривній єдності постають великі уми людства, серед яких художник Леонардо да Вінчі.

Символічна композиція «Портрет Учителя. Микола Стороженко» (2014-15) (іл. 1) написана Петруком в останні роки життя майстра. Знизу вгору по вертикалі зображені перо (знак повітря, Духа) і портрет Т. Г. Шевченка. Створюючи цикл «Мій Шевченко» (1984-05), М. А. Стороженко проніс образ поета через своє серце, стаючи причетним до його великого духу. Подібна практика у християнстві здійснюється, наприклад, у хресній ході на Великдень, коли, повторюючи шлях Христа по Via della Rosa, вірянин через чуттєвий особистий досвід готується до осягнення надчуттєвого, духовного начала.

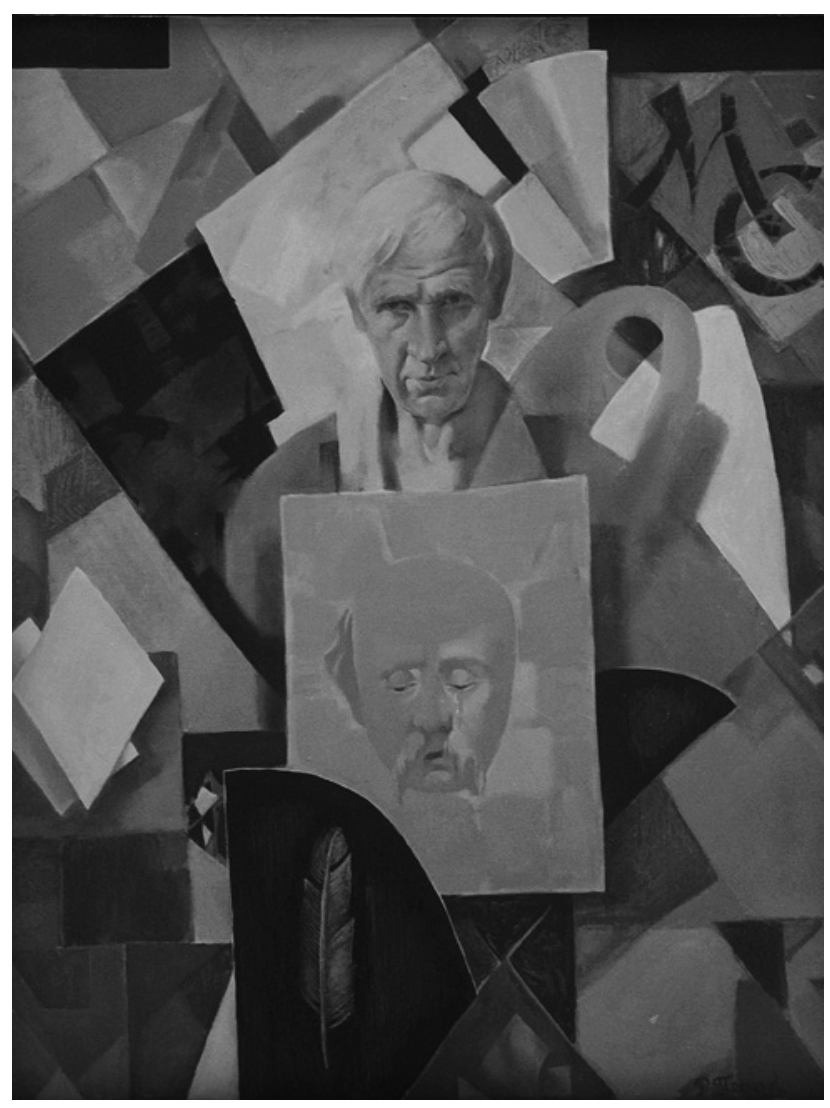

Іл. 1. Портрет Учителя. Микола Стороженко. П., комбінована техніка, 90х80, 2014-2015 рр. (1) 
У композиції Петрука портрети Шевченка і Стороженка об’єднані зображенням Пелікана, вигнута до грудей шия якого показана праворуч. Жертовний птах, що годує пташенят своїм тілом, слідуючи за християнською символікою, послужив емблемою Просвітництва. За часів атеїзму багато хто забув, що «освіта» - від слова «світло» - має божественну основу. Водночас, умовне зображення Пелікана може бути сприйняте як мальовнича палітра - духовний меч художника-просвітителя. Пелікан образ незакінченого панно Миколи Андрійовича «Наш Пелікан», в якому метафорично передано сприйняття особистості і творчості Кобзаря. Спогад про Стороженка його учень також назвав «Наш Пелікан». Повторивши назву, Петрук об'єднав особистості великого поета і свого вчителя темою жертовного служіння (Петрук, Наш Пелікан).

Композиція побудована на канонічному для іконопису фронтальному зображенні. Симетрія і врівноваженість протистоять потокові часу. Уважний погляд М. А. Стороженка запрошує глядача долучитися до діалогу. Через очі відбувається духовне спілкування. Наприклад, єгиптяни зображували око тільки в фас. У культурі Єгипту - це портал, за допомогою якого відбувався зв'язок людини з богом.

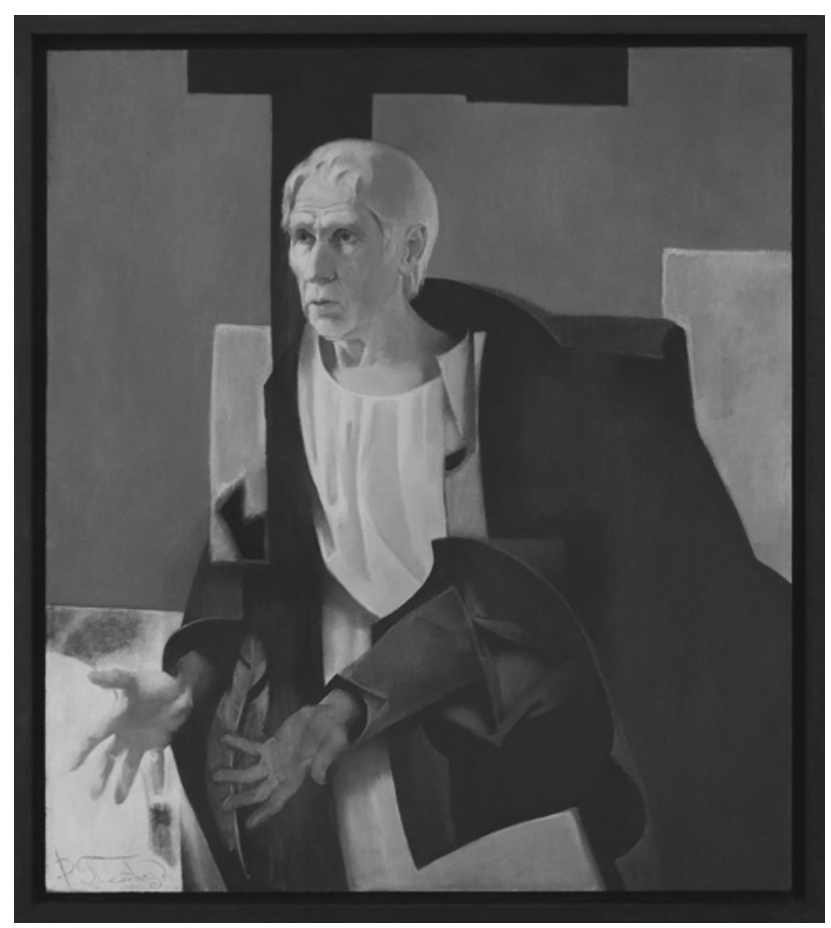

Іл. 2. Апостол. Микола Стороженко. П., комбінована техніка. 90х90. 2015-2016 рр. (1)
Портрет Т. Г. Шевченка був створений Стороженком (а потім і в композиції Петрука) на основі посмертної маски поета з використанням іконографії Спаса Нерукотворного. Все мистецтво творення образу - це діапазон між маскою (ликом) і портретом. Павло Флоренський писав, що в давнину «маски зовсім не були масками, як ми це розуміємо, але були різновидом ікон» (29). Маска і лик повертає нас до «роду», «пращура», далі - до божественного, надособистісного, першообразу, архетипу. Ми бачимо обличчя людини в контрасті його трансформації: об’ємно-пластичне трактування реалістичного портрета Стороженка змінюється прозорими іконописними «плавями» скорботного вигляду Кобзаря. Порівняння образу Шевченка з іконою Спаса Нерукотворного, написаної Романом у 2015-2016 роках, показує їхній взаємозв'язок і відмінність. В іконі стверджується домінанта умиротвореного духу, а в психологічному портреті важливою $є$ емоційність. Поет-заступник - це своєрідний міст між зримим i незримим світами.

Фізичний простір реального світу для творчості Петрука «не актуальний», важлива «енергія площини». Фон композиції «Портрет Учителя. Микола Стороженко» написаний в драматичних ритмах авангарду 1910-х - початку 1920-х років. Водночас трактування тла відповідає реальному творчому методу роботи над масштабною композицією в майстерні Стороженка, де в пошуках потрібного вирішення робили виправлення на наклеєних на картон чистих аркушах паперу. За словами художника, так виражається «хаос, з котрого народжується гармонія». Справа вгорі на теплій червоно-золотистій основі позначена монограма М C - Микола Стороженко. Домінує холодна гамма: від синьо-чорних кольорів бездонного нічного неба до прозорої блакиті ранкового сфумато. Холодні блакитні тони, в яких Петрук часто пише і обличчя, відповідають домінанті духу. «Я з Волині. Волинь синьоока вода, туман,- пояснює художник. - В блакитних тонах більше містики, таємниці» (Розмова 1).

Слова «Дух» і «духовність» мають споріднену основу. Вищий прояв одухотвореної людини - екстаз. Стан переживання «моменту істини» любили передавати майстри бароко, зокрема, улюблений Романом Ель Греко. Для вираження духу важливий сюжет - як для режисера, так і для художника. 
У груповому портреті композиції «Похорон графа Оргаса» передано стан осяяння грандів при спогляданні «відкритого неба». Подібний стан різною мірою може переживати художник у момент творчості.

Глибинну суть портрета «Апостол. Микола Стороженко» (2015-2016) (іл. 2) Петрук визначає словами: «Освячений духом животворящим». Портрет завершено після смерті майстра, «коли вже немає людини, а він зі мною». Учитель представлений як апостол, який несе Істину. Стан натхнення виражено в потужному русі постаті, у вихрових складках духовних шат. Жест відкритих, неначе чаша, даруючих рук, звернений до учнів, які слухають Слово. В характері руху Стороженка не випадковою є аналогія 3 позою Христа, що дарує хліб у зображенні Свхаристії композиції майстра «Передчуття Голгофи».

На темному тлі біля рук зображено біле перо. У культурі Стародавнього Сгипту, за якою (як переконливо показав у «Іконостасі» П. Флоренський, була генетично пов'язана символіка християнства) перо було атрибутом крилатої богині істини Маат. Під час суду Осіріса серце чистої людини мало бути легшим за пташине перо.

Полум'яне слово позначене теплим червоним кольором тла 3 золотисто-жовтими променями (світловими плямами) божественної присутності. Червоний колір в іконі означає духовне горіння. Водночас - це символ землі, заплідненої енергією світла. За словами Романа, помаранчевий відтінок відповідає також властивій для вчителя душевній теплоті. Композиція вписана у форму, близьку до квадрата. Квадрат - символ землі.

Структура композиції має основу в динамічному хресті, духовна вертикаль якого розташована зліва від центру, а темна горизонталь - у верхній частині полотна. Архетип хреста означає поєднання світу горішнього і долішнього. У хрещатому німбі Христа виражено возз'єднання небесного і земного через жертву, завдяки якій людина отримала можливість вічного життя. В організації простору Петрук інтуїтивно дотримується пропорцій «золотого перетину» по вертикалі й по горизонталі.

За образним висловом Романа, «лінія в композиції - цее кардіограма». Подібним чином можна визначити його композицію, в якій відображені ритми епохи змін. У портреті Стороженка висхідна діагональ стрімкого руху, окриленого лицарським плащем торса, веде до одухотвореного обличчя. Срібло волосся виявляє сферу голови (небо). Напрямок руху справа наліво психологічно викликає відчуття подолання інертного. Жест рук, зображених у нижній частині перехресної падаючої діагоналі, повертає рух долі.

Темна вертикаль прапора-хреста символічно стверджує вертикаль духу і тональним контрастом дозволяє передати світло. Біла сорочка (символ чистоти) являє своєрідний п'єдестал для голови (споріднений з класичною гермою). Улюблене візантійцями поєднання золотисто-жовтого і фіолетового свідчення вищого ступеня в духовному сходженні. Золотий клав на одязі викликає асоціації зі знаком посланця на гіматії центрального ангела «Трійці» А. Рубльова. Внутрішнє світло фіолетового плаща нагадує «пробіла» древніх фресок. Флоренський писав про іконописні «плаві», що ущільнюються відповідно до «ступенів явленності буття» (139). «Учитель казав, що між складками - ефір - це «вітер» без напряму; що в процесі роботи найпочесніше опрацю-

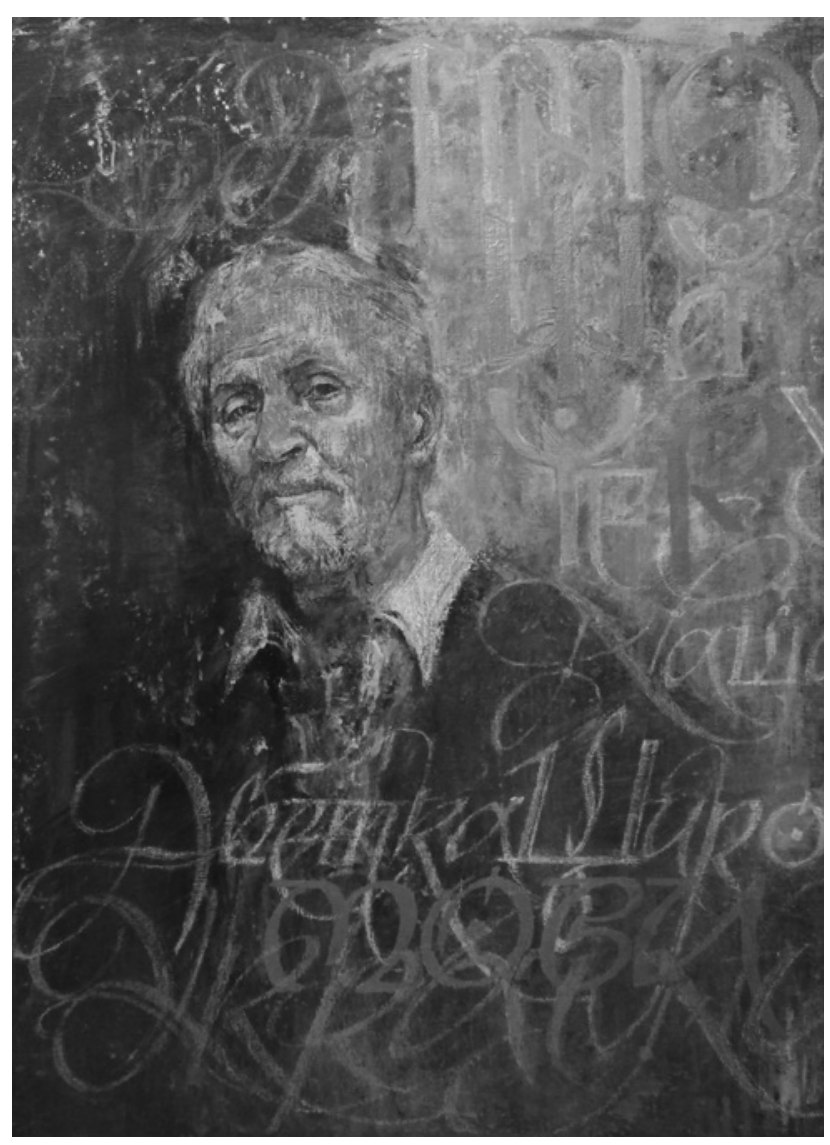

Іл. 3. Василь Чебаник. Батько Абетки Щирої Мови України. П.,о., $80 \times 70$ см., 2017-2018 рр. 


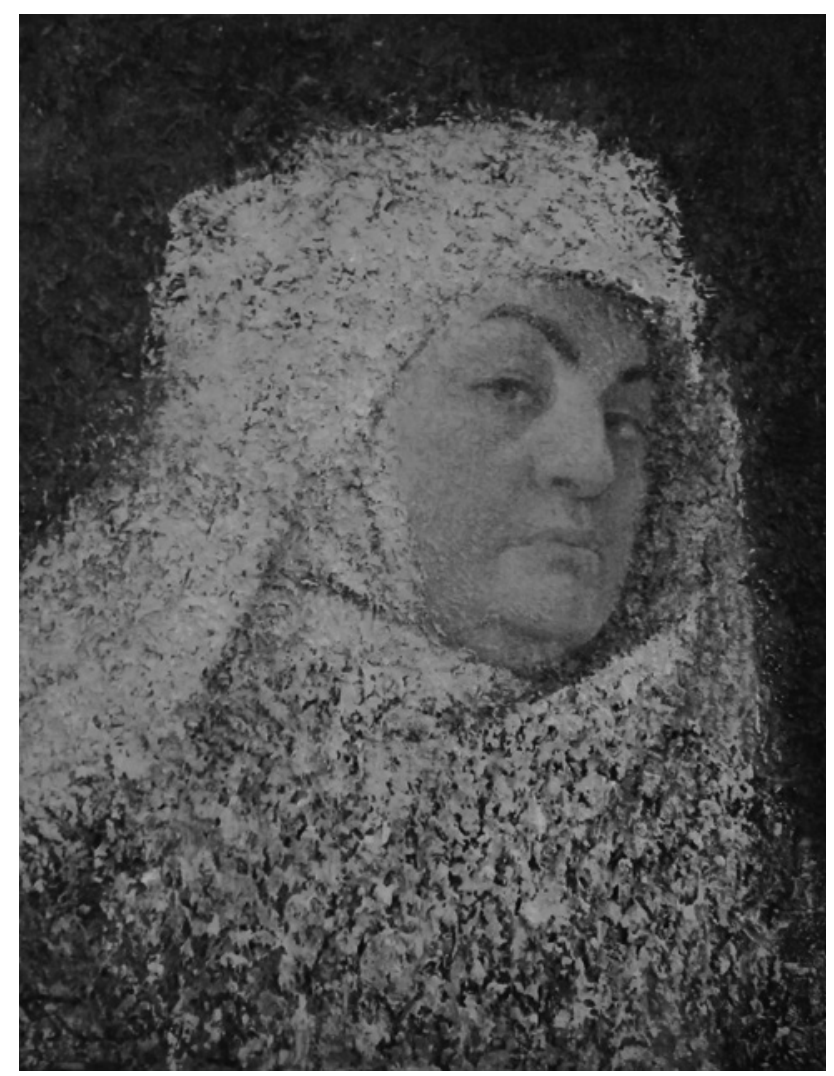

Іл. 4. Раїса Стороженко.

П.,o. 50x45. 2016 (1)

вати не складку, а ефір; шукати динаміку глибини в глибинах, рух метафізичний», - згадує Роман (Петрук, Освячений 174).

Портрет був створений у стилістиці, спорідненій самому М. А. Стороженкові, орієнтованій на відродження українського бароко, в якому він бачив втілення національного стилю: «Бароко - національна ознака». Для Петрука, як і для Стороженка, близька емоційність бароко. Створюючи символічний простір, художник відмовляється від гравітації. Нижня частина композиції зліва світла, оскільки, за словами Романа, «Стороженко - людина, яка летить тілом і духом» (Розмова 3).

у портреті харизматичної особистості М. А. Стороженка можна помітити зв'язок 3 портретами майстрів авангарду. За часів уніфікації індивідуальності К. С. Малевич утверджував не обмежену ідеологією вищу ієрархію художника-творця. Творець супрематизму зобразив себе в образі посвяченого в таїнства Магістра «Автопортрет» (1933). Підтвердженням символічно-значущої ролі одягу й умовного фону є також створений ним «Чоловічий портрет» (М. М. Пунін?) (1933), де образ апологета мистецтва авангарду асоціюється 3 лицарем-хрестоносцем. Художники модерну (Врубель) i, особливо, авангарду (Татлін, Лентулов, Бурлюк) стверджували свою духовну міць і здатність не тільки перетворювати світ силою мистецтва, а й створювати нові світи (Тарасенко, Мистерии).

«Музика і ритми шрифтів мене дуже надихають», - розповідає художник. Композиція «Василь Якович Чебаник. Батько Абетки щирої мови України» (2017) (іл. 3) створена у співавторстві з видатним каліграфом, наповнила магічним змістом простір портрета. Він повертає забутий зміст літері, а разом 3 нею і «самовитого слова» (за висловом О. О. Потебні). Разом з портретом, літери ніби проявляються зі вселенської темряви, нагадуючи біблійне: «Спочатку було Слово». Фон створює енергетичний тонус, що потужно впливає на підсвідомість глядача.

3 темряви виступає світлий образ дружини Миколи Андрійовича, українського філолога Раїси Олександрівни Стороженко в намітці (2016) (iл. 4). Умовний простір вимикає людину з конкретної життєвої ситуації, тобто залучає до вічності. Тональний контраст темного і світлого символізує діапазон життя - смерті - безсмертя. У графічних портретах художників-вчителів: I. А. Ковтонюка, В. І. Баринової-Кулеби, О. П. Цугорка Роман передав любов і вдячність. Всі портрети створені у власній стилістиці. Петрук шукає форму втілення індивідуальної психології особистості: «У кожної людини свій темперамент, своє енергетичне поле і його треба передати через колір, фактуру, ритми складок чи тональних плям».

Ангели Фра Анжеліко та Пінзеля надихають Романа. У портреті «Актор Олександр Піскунов» (2015-2016) (іл. 5) художник не пише фігуру артиста, а зосереджує увагу на його обличчі й уважному погляді. Іконографія стрімкого руху юнака має віддалену спорідненість з поривом архангела Гавриїла в зображенні Благовіщення, який долає кордони чуттєвого $\mathrm{i}$ надчуттєвого світів. Кожне народження картини, як i людини, - втілення Духа в матерію. Завдяки нашій уяві повітряний шарф Олександра ніби трансформується в крила. Психологічний стан актора виражений у динамічному ракурсі, властивому стилістиці бароко. Рух душі передано в просторі тла. Виникають асоціації з грою світла кольорового вітража на кам'яних 
стінах інтер'єру готичного храму, де разом із рухом сонця постійно змінюється гама кольорів. У композиції «Ноктюрн» (2011), на яку Романа надихнула музика Шопена, показано, як відбувається одухотворене перевтілення людини завдяки мистецтву. Образ створювався в різний час із декількох моделей.

Фотоапарат фіксує, насамперед, плани фізичного і душевного життя. 3 його допомогою не можна створити ікону, тобто, передати духовну реальність в особі людини, створеної «за образом і подобою» божественного начала. Трансцендентне видиме внутрішніми очима. У кожному дотику пензля до полотна або паперу втілена енергія: «Через фактуру передаються почуття, - каже Роман. - Фото робиться за частку секунди, а портрет пишеться довго. Поки пишеш - багато обдумуєш, переживаєш. Портрет - поєднання в часі» (Розмова 2). Так, наприклад, портрет академіка В. І. Гуріна створювався за ескізами, зробленими упродовж восьми років. 3 різних психологічних станів народжується «формула особистості», яка постає в кращі хвилини життя.

Висновки. Програмова для М. А. Стороженка тема зв'язку роду і народу продовжена в портретних образах його учня. У композиціях Романа Петрука світське і культове мистецтво виявилося співзвучним. Одухотворені люди - ті, що несуть в собі вічність. Саме вони гідні бути увічненими. В портретах М. А. Стороженка, викладачів НАОМА, творчих людей України Петрук виявляє вічний дух за допомогою виразних засобів образотворчого мистецтва.

Творчість - дотик до вічності. Тому людина відчуває захват, перебуваючи в стані духовного одкровення. Роман шукає втілення вічного духу в реальних людях. Створена ним галерея портретних образів (понад 100 творів живопису і графіки) свідчення духовної битви художника за домінанту духу над матерією: «Бо мистецтво, це часово и просторово осмислений рух на створення узагальненого образу у віках» (Розмова 2).

Культура спрямована на гармонію. Упродовж тисячоліть вироблялася і трансформувалася художня мова, за допомогою якої передавався зв'язок тимчасового і вічного, побуту і буття. Полістилізм сучасного мистецтва передбачає можливість знати образотворчу мову роду, народу і людства в цілому. Розглянуті нами особливості композиції, символіки та стилістики творів Петрука у контексті

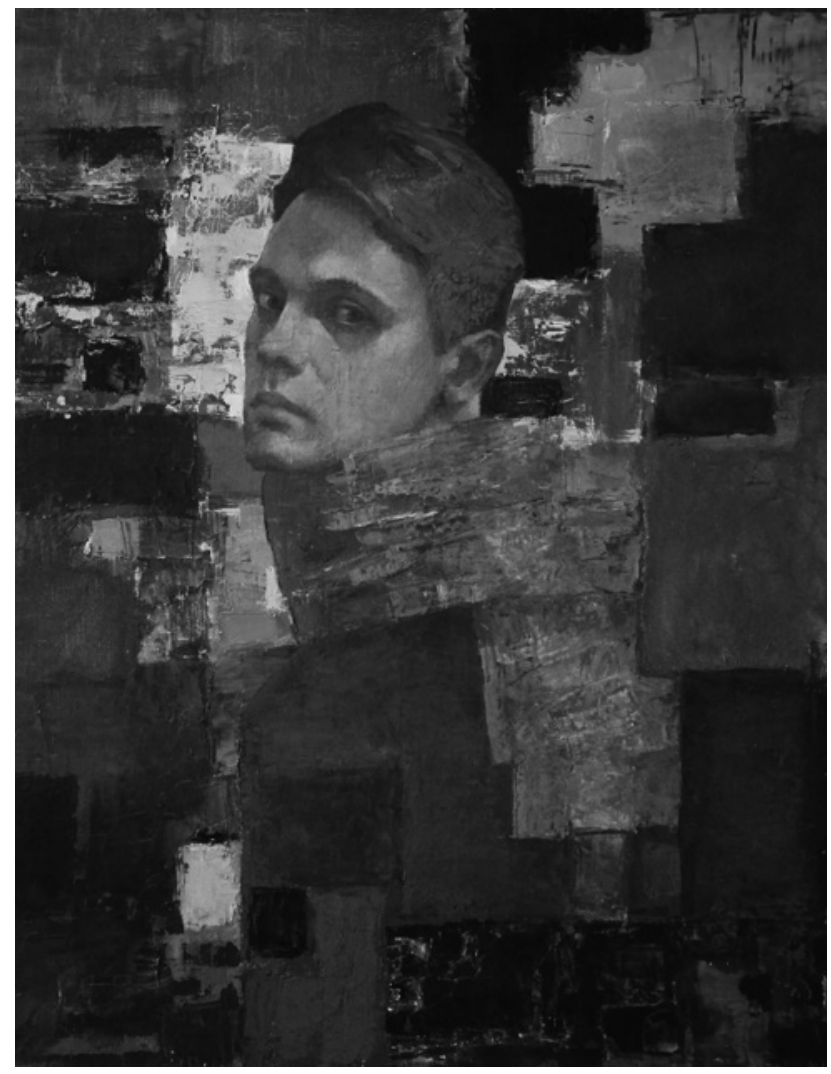

Іл. 5. Актор Олександр Піскунов. П., о., $80 x 70$ см., 2014-2016 pp. (1)

мистецтва світового портрета свідчать про те, що в його творчості поєднуються спадщина мистецтва Давньої Русі і Візантії, європейського та українського бароко, романтизму, академізму та сучасних напрямків. Неосинтетизм - так іменує свій творчий метод Петрук.

«Роману Петруку. Освяченому у Провидінні на подвиг Лицарський, на необоримість Щита Чеснот 3 Іменем: «Україна». Микола Стороженко з вірою і Любов’ю», - так майстер підписав учневі свою останню книгу «Микола Стороженко. Мій Шевченко» (2015). За часів масової матеріалізації свідомості, слідом за Учителем, разом з іншими учнями і послідовниками, мовою образотворчого мистецтва Роман Петрук стверджує тезу Григорія Савича Сковороди: «Плоть ничтоже, дух животворящ» (Сковорода 58).

Перспективи використання результатів дослідження. Матеріали статті можуть бути використані істориками мистецтва при створенні монографії про художню школу М. А. Стороженка, викладачами вищих художніх навчальних закладів для викладання теми: «Жанр портрета». 


\section{Цитовані праці}

Белецкий, Платон. Украинская портретная живопись XVII-XVIII вв. Ленинград: Искусство, 1981. Печать. Бритова, Н. Н., Лосева, Н. М., и Сидорова, Н. А. Римский скульптурный портрет. Москва: Искусство, 1975. Печать.

Виппер, Б. Р. Статьи об искусстве. Москва: Искусство, 1970. Печать.

Михайлова, Рада. «Музична палітра Романа Петрука». Київ 3-4 (2018): 186-192. Друк.

Микола Стороженко. Передчуття Голгофи: Док. фільм. Авт. Віктор Політов. Київ: 24 Листоп. 2015. Youtube. Веб. 19 Жовт. $2018<$ https://www.youtube.com/watch?v=LpwuN-Kxlek>.

Петрук, Роман. «Наш Пелікан». Образотворче мистеитво 4 (2017): 40-41. Друк.

Петрук, Роман. «Освячений духом животворящим». Образотворче мистецтво 1 (2015): 72-175. Друк.

Розмова Ольги Тарасенко з Романом Петруком 20 червня, 2018. [Архів автора]. [Б. м.], [2018]: 1-3. Друк.

Сковорода, Григорій Савич. Байки харківські. Афоризми. Харків, 1972. Друк.

Тарасенко, О. А. Мистерии модернизма. Наследие Древней Руси в живописи модерна и авангарда. Одесса: Абрикос, 2004. Печать.

Тарасенко, О. А. «Портрет і ритуал». Мистеитвознавство України 5 (2005): 56-68. Друк.

Флоренский, Павел. Иконостас. Избранные труды по искусству. Санкт-Петербург: Мифрил, 1993. Печать.

\section{References}

Beletskiy, Platon. Ukrainskaya portretnaya zhivopis XVII-XVIII vv. Leningrad: Iskusstvo, 1981. Pechat.

Britova, N. N., Loseva, N. M. i Sidorova N. A. Rimskiy skulpturnyiy portret. Moskva: Iskusstvo, 1975. Pechat.

Vipper, B. R. Stati ob iskusstve. Moskva: Iskusstvo, 1970. Pechat.

My’xajlova, Rada. «Muzy`chna palitra Romana Petruka». Kyiv 3-4. (2018): 186-192. Pechat.

Mykola Storozhenko. Peredchuttia Holhofy: Dok. film. Avt. Viktor Politov. Kyiv: 24 Lystop. 2015. Youtube. Web.

19 Oct. 2018. <https://www.youtube.com/watch?v=LpwuN-Kxlek>.

Petruk, Roman. «Nash Pelikan». Obrazotvorche my`stecztvo 4 (2017): 40-41. Pechat.

Petruk, Roman. «Osvyacheny’j duxom zhy`votvoryashhy`m». Obrazotvorche my'stecztvo 1 (2015): 72-175. Pechat.

Rozmova Olhy Tarasenko z Romanom Petrukom 20 chervnia, 2018: [Arkhiv avtora]. [B. m.], [2018]: 1-3. Druk.

Skovoroda, Gry`gorij Savy'ch. Bajky’xarkivs'ki. Afory`zmy'. Xarkiv, 1972. Druk.

Tarasenko, O. A. Misterii modernizma. Nasledie Drevney Rusi v zhivopisi moderna i avangarda. Odessa: Abrikos, 2004. Druk.

Tarasenko, O. A. «Portret i rytual». Mystetstvoznavstvo Ukrainy 5 (2005): 56-68. Druk.

Florenskiy, Pavel. Ikonostas. Izbrannyie trudyi po iskusstvu. Sankt-Peterburg: Mifril, 1993. Pechat.

Подано до редакиії 19.10.2018 